\title{
Agricultural residues as a substrate in the production of eggplant seedlings
}

\author{
Lorena AM Meneghelli'; Paola AVL Monacoㅎ ${ }^{1}$ Ismail R Haddade ${ }^{1}$; Caroline M Meneghelli²; Karoline M \\ Almeida ${ }^{1}$
}

${ }^{1}$ Instituto Federal de Educação, Ciência e Tecnologia do Espírito Santo (IFES), Santa Teresa-ES, Brasil; lorena.merlo@hotmail.com; paolalm@ifes.com.br; ihaddade@gmail.com; karolinematiello@hotmail.com; ${ }^{2}$ Universidade Federal do Espírito Santo, Alegre-ES, Brasil; carol.merlo@hotmail.com

\begin{abstract}
The objective of this study was to evaluate the growth variables of eggplants seedlings produced in substrates with different compositions in agricultural residues. The experiment was carried out in a completely randomized design, with five treatments and ten replicates, with the following treatments: $\mathrm{T} 0=$ Bioplant commercial substrate (control); T1 $=10 \%$ of moinha (dried residue of coffee beans) $+15 \%$ of coconut fiber $+5 \%$ of eggshell $+70 \%$ of commercial substrate; T2 $=20 \%$ of moinha $+15 \%$ of coconut fiber $+5 \%$ of eggshell $+60 \%$ of commercial substrate; $\mathrm{T} 3=30 \%$ of moinha $+15 \%$ of coconut fiber $+5 \%$ of eggshell $+50 \%$ of commercial substrate; $\mathrm{T} 4=40 \%$ of moinha $+15 \%$ of coconut fiber $+5 \%$ of eggshell + $40 \%$ of commercial substrate. The evaluated variables were electric conductivity of the substrate, number of leaves, plant height, stem diameter; and fresh and dry biomass of shoot, root, and of the whole plant. Growing doses of moinha provide increased electrical conductivity in substrate. The treatment groups containing increasing proportions of moinha in the substrate composition present the highest values of growth variables in relation to the commercial substrate. Except shoot, root and total dry biomass, the substrate with 10 and $20 \%$ of moinha have the highest values of analyzed variables in eggplant seedlings.
\end{abstract}

Keywords: Solanum melongena, vegetables, moinha, growth variables.

\section{RESUMO}

Resíduos agrícolas como substrato na produção de mudas de berinjela

Avaliaram-se as variáveis de crescimento de mudas de berinjela produzidas em substratos com diferentes composições de resíduos agrícolas. O experimento foi realizado no delineamento inteiramente casualizado, com cinco tratamentos e dez repetições, sendo os tratamentos: $\mathrm{T} 0=$ substrato comercial Bioplant (testemunha); $\mathrm{T} 1=10 \% \mathrm{de}$ moinha (resíduo da secagem dos grãos de café) $+15 \%$ fibra de coco $+5 \%$ casca de ovo $+70 \%$ substrato comercial; $\mathrm{T} 2=20 \%$ de moinha $+15 \%$ fibra de coco $+5 \%$ casca de ovo $+60 \%$ substrato comercial; T3: $30 \%$ de moinha $+15 \%$ fibra de coco $+5 \%$ casca de ovo $+50 \%$ substrato comercial; T4: $40 \%$ de moinha $+15 \%$ fibra de coco $+5 \%$ casca de ovo $+40 \%$ substrato comercial. Foram avaliados a condutividade elétrica do substrato, número de folhas, altura de plantas, diâmetro do coleto; e massas frescas e secas da parte aérea, raiz, e da planta completa. Níveis crescentes de moinha proporcionam aumento da condutividade elétrica no substrato. O grupo de tratamentos contendo proporções crescentes de moinha na composição do substrato apresenta os maiores valores das variáveis de crescimento em relação ao substrato comercial. À exceção das variáveis massa seca da parte aérea, de raiz e total, o substrato contendo entre 10 e $20 \%$ de moinha proporciona os maiores valores das variáveis analisadas em mudas de berinjela.

Palavras-chave: Solanum melongena, hortaliça, moinha, variáveis de crescimento.

Received on June 16, 2016; accepted on April, 17, 2017

$I_{\text {ns }}^{n}$ Brazil over the past years there has been a considerable increase in vegetable consumption, primarily eggplant (Solanum melongena) (Anefalos et al., 2008).

Within the productive chain of vegetables, the formation of seedlings is one of the most important phases for the crop cycle, influencing the plant's performance in field, and nutritional and productive point of view (Campanharo et al., 2006).
One of the factors that directly affect the seedlings quality is the type of substrate used, since it must present physical and chemical characteristics that provide the seedling a good development, resulting in healthy and vigorous plants. According to Silva Júnior et al. (2014), substrate for cultivation should provide adequate supply of air and water to the root system, besides supporting the plants. Steffen et al. (2010) reinforce that the choice of a substrate for oleraceous seedlings production should be based on two essential criteria: the cost of acquisition and the availability of the material for substrate production.

Commercial substrates are generally used in eggplant seedlings production, however there is an additional cost in the seedlings production stage. The use of agricultural residues available on farms for the seedlings production is an economically viable source of nutrients 
because it reduces the costs of acquiring commercial substrates (Araújo Neto et al., 2009). In addition, it is a way to minimize the environmental impact caused by incorrect residues disposal in the environment.

In order to use the residues generated in each region, in addition to improving the physical and chemical characteristics of the substrate, several researches have been carried out with different commercial and alternative substrates in eggplant seedlings, highlighting the studies of Costa et al. (2011, 2012), Ferreira et al. (2014), among others.

Among the residues that are generated in high amounts in the state of Espírito Santo with a potential to be used as alternative substrates for the eggplant seedlings production, moinha, coconut fiber and eggshell are the ones that stand out. According to Meneghelli et al. (2016), moinha are composed of leaves, branches, remains of inflorescences and poorly formed coffee beans which, when dried, are burned and released from the dryer of coffee. The same authors, when chemically characterizing this material, found high contents of nitrogen, phosphorus and potassium. Another residue that can be used for substrates composition is coconut fiber, due to its physico-chemical characteristics, which favor the root formation (Castoldi et al., 2014), due to its high porosity and moisture retention (Araméndiz-Tatis et al., 2013), besides being a renewable raw material (Carrijo et al., 2002).

Eggshell has calcium carbonate as a main component in its composition (Naves et al., 2007), and can be used as one of the nutritional components for the substrate formulation.

The objective of this study was to evaluate the growth variables of eggplant seedlings produced in substrates with different compositions of agricultural residues.

\section{MATERIAL AND METHODS}

The experiment was carried out in the greenhouse of the Instituto Federal do Espírito Santo, Campus Santa Teresa, in the municipality of Santa Teresa, Espírito Santo State, Brazil $\left(18^{\circ} 48^{\prime} \mathrm{S}, 40^{\circ} 40^{\prime} \mathrm{W}\right.$, altitude $\left.130 \mathrm{~m}\right)$. The climate, according to the Köppen classification, is type Cwa (subtropical of dry winter), with an annual average temperature of $24.6^{\circ} \mathrm{C}$ and an annual average precipitation ranging from 700 to $1200 \mathrm{~mm}$. The temperature and relative humidity of the air in the experimental period ranged from 19.9 to $38.2^{\circ} \mathrm{C}$ and 47.5 to 69.5 , respectively. The greenhouse where the study was conducted was covered with $50 \%$ of shade.

The residues used in the alternative substrate for the eggplant seedlings production are from the dried coffee beans called moinha, coconut fiber and eggshell. The moinha was used as it was collected without any grinding or sieving treatment. Coconut fiber was air dried and processed into a disintegrator, afterwards sieving the particle to a size of 1 to $10 \mathrm{~mm}$. The eggshell was crushed into powder.

The chemical and physicochemical characterization of residues used in the substrates composition was carried out at the Soil and Solid Residue Laboratory of the Agricultural Engineering Department of the Federal University of Viçosa. The physicochemical analysis determined the electrical conductivity (EC), through a bench conductivity meter. The chemical analysis determined the $\mathrm{pH}$ using a bench potentiometer, and easily oxidizable organic carbon, total organic carbon, total nitrogen, phosphorus and potassium were determined following the methodology described by Matos (2015). Table 1 presents the chemical and physico-chemical attributes $(\mathrm{CP})$ of the moinha, coconut fiber and eggshell used in the experiment.

The experimental design was completely randomized, with five treatments and ten replicates. Each experimental unit consisted of 20 seedlings, totaling 1,000 seedlings throughout the experiment. Six central plants were considered useful for each experimental unit.

The evaluated treatments were $\mathrm{T} 0=$ Bioplant commercial substrate (control); $\mathrm{T} 1=10 \%$ of moinha (dried residue of coffee beans) $+15 \%$ of coconut fiber + $5 \%$ of eggshell $+70 \%$ of commercial substrate; T $2=20 \%$ of moinha $+15 \%$ of coconut fiber $+5 \%$ of eggshell + $60 \%$ of commercial substrate; $33=30 \%$ of moinha $+15 \%$ of coconut fiber + $5 \%$ of eggshell $+50 \%$ of commercial substrate; T $4=40 \%$ of moinha $+15 \%$ of coconut fiber $+5 \%$ of eggshell $+40 \%$ of commercial substrate. The amount of residues added to the treatments was calculated on a volume basis.

The chemical attributes of the commercial substrate Bioplant, obtained by Paixão et al. (2012), were 0.62; 1.55; $0.44 ; 1.84$ and $21.0 \mathrm{dag} / \mathrm{kg}$ for nitrogen, phosphorus, potassium, calcium and total organic carbon, respectively, and 5.62 for $\mathrm{pH}$.

The eggplant seeds from cultivar Embú were sown in plastic containers with 200 cells, placing two seeds per cell.

The seedling production system was used in suspended containers, placed in masonry benches, hand irrigated twice a day, in the morning and in the afternoon, and fertilizer was not used.

Fifteen days after sowing (DAS),

Table 1. Chemical and physico-chemical attributes (EC) of moinha (MO), coconut fiber (CF) and eggshell (ES) used in the experiment. Santa Teresa, IFES, 2016.

\begin{tabular}{lcccccccc}
\hline \multirow{2}{*}{ Residues } & $\mathbf{p H}$ & $\mathbf{E C}$ & $\mathbf{O C}$ & $\mathbf{T O C}$ & $\mathbf{N}_{\mathbf{T}}$ & $\mathbf{P}$ & $\mathbf{K}$ & $\mathbf{C a}+\mathbf{M g}$ \\
\cline { 6 - 10 } & & $\mathbf{( d S / m )}$ & \multicolumn{6}{c}{$\mathbf{( d a g} / \mathbf{k g})$} \\
\hline $\mathrm{MO}$ & 5.60 & 6.49 & 45.3 & 58.9 & 3.7 & 0.14 & 0.71 & - \\
$\mathrm{CF}$ & 7.15 & 0.09 & 57.1 & 74.1 & 0.66 & 0.053 & 0.14 & - \\
$\mathrm{ES}$ & 9.37 & 0.37 & 2.8 & 3.6 & 0.87 & 0.084 & 0.06 & 31.9 \\
\hline
\end{tabular}

${ }^{1} \mathrm{pH}$ measured in water; $\mathrm{EC}=$ electrical conductivity; $\mathrm{OC}=$ oxidizable organic carbon; $\mathrm{TOC}=$ total organic carbon; $\mathrm{NT}=$ total nitrogen; $\mathrm{P}=$ phosphorus; $\mathrm{K}=$ potassium; $\mathrm{Ca}+\mathrm{Mg}=$ calcium + magnesium. 
thinning was performed, leaving only one plant per cell.

The evaluations were carried out at $25 \mathrm{DAS}$, determining the electrical conductivity of the substrates [using a conductivity meter, following a methodology proposed by Matos (2015)], counting the number of leaves, measuring the plant height (with the aid of a millimeter ruler, measuring from the base of the stem to the apical bud from the last leaf), stem diameter (using digital caliper), fresh biomass and shoot, root and whole plant dry biomass. The dry biomass of the aerial plant part was obtained by cutting the seedlings close to the substrate. To obtain the root dry biomass, the roots were carefully washed in running water, on a sieve. Subsequently, they were placed in paper bags in a greenhouse submitted to a temperature of $65^{\circ} \mathrm{C}$ during 72 hours. The materials were weighed in an electronic precision scale of $0.01 \mathrm{~g}$.

The data from the evaluated variables were submitted to test of normality (Lilliefors), homoscedasticity (Barttlet), and Tukey's additivity test in order to perform the analysis of variance. The qualitative difference between the commercial substrate treatment (T0) and the other treatments (T1 to T4), due to the absence of moinha, coconut fiber and eggshell in the analysis of variance for qualitative treatments was performed only considering the decomposition of the sums of squares of the treatments, the contrast between the $\mathrm{T} 0$ and the other treatments. For the comparisons between the treatments T1, T2, T3 and T4 related to the level of moinha (quantitative treatments), the decomposition of degrees of freedom of the treatments in regression models by the orthogonal polynomials method was adopted as a procedure. For the procedures, an " $\alpha$ " of 0.05 was adopted. All the statistical analyzes were performed by the SAEG 9.1 program.

\section{RESULTS AND DISCUSSION}

Table 2 shows the contrast values and the significance levels between the conventional substrate treatment and the treatments with the different levels of moinha.

The treatments with moinha (10 to $40 \%$ ) were higher to the treatment that only used commercial substrate for all the variables evaluated, since the estimators of the contrasts for each variable were significant and negative $(\mathrm{p}<0.05)$.

It is believed that such results may be related to the higher amount of nutrients present in the moinha, especially nitrogen (Table 1), when compared to the commercial substrate. According to Natale et al. (2008), nitrogen deficiency in seedlings compromises the development of the plant and reduces the accumulation of dry biomass. Taiz \& Zeiger (2009) reinforce that nitrogen is considered to be one of the most relevant factors for increasing plant production, as it influences the emergence rate and the leaf area expansion. Thus, the smaller amount of nitrogen in the commercial substrate may have compromised the plant development as a whole, reducing the accumulation of dry biomass.

It should be noted that the use of eggshell and coconut fiber in the proportions used in this study may have positively contributed to the seedlings development. The eggshell contributes especially with calcium (Table 1), when compared to the amount present in the commercial substrate presented by Paixão et al. (2012). Coconut fiber may have contributed to the substrate physical quality, providing adequate aeration and water retention. Figures 1A-J show the electrical conductivity (EC), number of leaves (NL), plant height $(\mathrm{PH})$, stem diameter (SD), fresh shoot biomass (FSB), fresh roots biomass (FRB), total fresh biomass (TFB), shoot dry biomass (SDB), root dry biomass (RDB) and total dry biomass (TDB), respectively, due to the

Table 2. Coefficients, significance levels and contrasts estimators between conventional substrate treatment and those with different levels of moinha in the substrate. Santa Teresa, IFES, 2016.

\begin{tabular}{|c|c|c|c|c|c|}
\hline Conventional & $10 \%$ & $20 \%$ & $30 \%$ & $40 \%$ & Estimator \\
\hline \multicolumn{6}{|c|}{ Electrical conductivity $(\mathrm{EC})(\mu \mathrm{S} / \mathrm{cm})$} \\
\hline 21 & 73 & 119 & 142 & 187 & -437.00 \\
\hline \multicolumn{6}{|c|}{ Number of leaves (NL) } \\
\hline 4.58 & 5.86 & 6.39 & 5.58 & 5.28 & -4.80 \\
\hline \multicolumn{6}{|c|}{ Plant height (PH) (cm) } \\
\hline 5,64 & 9,22 & 10,00 & 7,78 & 6,67 & -11.13 \\
\hline \multicolumn{6}{|c|}{ Stem diameter $(\mathrm{SD})(\mathrm{mm})$} \\
\hline 0.41 & 0.80 & 1.00 & 0.68 & 0.46 & -1.29 \\
\hline \multicolumn{6}{|c|}{ Fresh shoot biomass(FSB) (mg) } \\
\hline 133.87 & 260.23 & 269.58 & 212.46 & 166.6 & -373.41 \\
\hline \multicolumn{6}{|c|}{ Fresh roots biomass(FRB) (mg) } \\
\hline 113.88 & 296.93 & 377.38 & 290.54 & 232.8 & -742.15 \\
\hline \multicolumn{6}{|c|}{ Total fresh biomass(TFB) (mg) } \\
\hline 247.74 & 557.17 & 646.96 & 503.01 & 399.39 & -1115.56 \\
\hline \multicolumn{6}{|c|}{ Shoot dry biomass(SDB) (mg) } \\
\hline 21.44 & 137.61 & 146.00 & 85.09 & 63.38 & 346.33 \\
\hline \multicolumn{6}{|c|}{ Root dry biomass(RDB) (mg) } \\
\hline 20.19 & 124.34 & 125.40 & 75.39 & 53.78 & -298.14 \\
\hline \multicolumn{6}{|c|}{ Total dry biomass (TDB) (mg) } \\
\hline 41.63 & 261.96 & 271.40 & 160.48 & 117.2 & -644.46 \\
\hline
\end{tabular}

Error $\alpha=0.0000$. 
increasing percentages of moinha in the substrate composition.

The variable EC showed a linear behavior in the regression analysis, whereas the variables NL, PH, SD, FSB, FRB, TFB, SDB, RDB, TDB, presented a quadratic polynomial behavior, due to the different percentages of moinha in the substrate composition in the eggplant seedlings.

Increasing amounts of moinha in the substrate provided increasing values of electrical conductivity (Figure 1A), in which $40 \%$ of moinha provided the highest EC (185 $\mu \mathrm{S} / \mathrm{cm})$. This result was foreseen, due to the moinha being a residue with high EC (Table 1). According to Harter et al. (2014), the high concentration of salts is a stress factor for plants, because it reduces the osmotic potential and provides

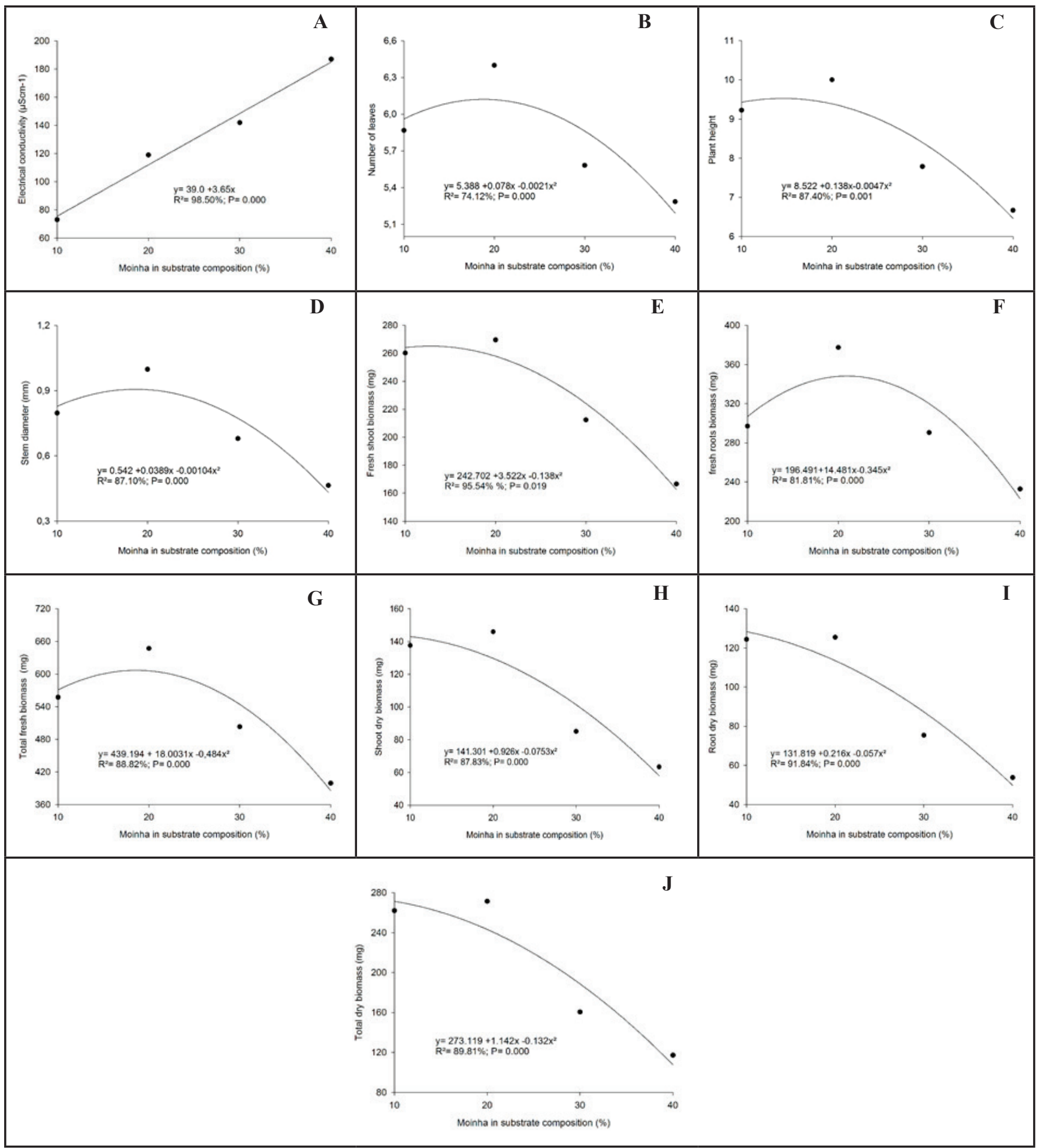

Figure 1. Electrical conductivity (a), number of leaves (b), plant height (c), stem diameter (d), fresh shoot biomass (e), fresh roots biomass (f), (continue) total fresh biomass (g), shoot dry biomass (h), root dry biomass (i) and total dry biomass (j), due to increasing percentages of moinha in the substrates composition. Santa Teresa, IFES, 2016. 
ion activity on protoplasm. The water is osmotically retained in the saline solution, so that the increased salt concentration is less available to the plants.

The number of leaves is a very important attribute for a good crop development, since the photosynthetic process is a result of light interception and its conversion into light chemical energy, which depends on the number and size of the leaves, as well as their time in the plant (Favarin et al., 2002). According to Figure 1B, the estimated percentage of $18.57 \%$ of moinha in the substrate composition provided a higher number of leaves (6.11), among the treatments applied. However, the lowest value (5.14 units) was obtained in the substrate containing $40 \%$ of moinha (Figure 1B).

The results obtained in this study, including the lower value due to the higher proportion of moinha, are superior when compared to the results found by Ferreira et al. (2014) and Moreira et al. (2010). Ferreira et al. (2014), studying the eggplant seedlings growth using vermicompost, obtained at 25 DAS, 3.56 units of leaves per seedling, the best result obtained among the treatments. Moreira et al. (2010), testing substrates based on bovine manure and small ruminants manure in different proportions in eggplant seedlings produced in protected environment, did not obtain a number of leaves higher than 3.562 units per plant at 25 DAS.

The best result obtained for the $\mathrm{PH}$ variable $(9.53 \mathrm{~cm})$ was in the substrate containing an estimated percentage of $14.68 \%$ of moinha, while the lowest value $(6.52 \mathrm{~cm})$ was obtained in the substrate containing $40 \%$ of moinha (Figure 1C). The lowest result obtained due to the higher dose of moinha was higher than the $3.9 \mathrm{~cm}$ obtained by Costa et al. (2011) in eggplant seedlings at 40 DAS produced in substrates with different percentages of shredded cassava stem and vermiculite and by Costa et al. (2012) who obtained heights varying between 1.95 and $2.43 \mathrm{~cm}$, at 40 DAS, in substrates containing $86 \%$ of Plantmax $+14 \%$ of organic compound. Ferreira et al. (2014) verified at 25 DAS, maximum heights of 11.256 and 11.140 $\mathrm{cm}$, in eggplant seedlings cultivated in substrates with bovine manure and small ruminants manure in different proportions.

In vegetables, the stem diameter is one of the fundamental characteristics when deciding if the seedling can be planted. According to Santos et al. (2010), the largest stem diameter shows that the plants are more vigorous. In this sense, it is verified that the estimated percentage of $18.7 \%$ of moinh a provided the highest value of the sample $(0.90$ $\mathrm{mm})$, while the lowest value $(0.434$ $\mathrm{mm})$ was obtained with the substrate containing $40 \%$ of moinha (Figure 1D). These results were lower than those found by several authors, such as Costa et al. $(2011,2012)$ and Ferreira et al. (2014). Costa et al. (2011) obtained averages between 1.28 and $1.83 \mathrm{~mm}$, in eggplant seedlings produced in different percentages of shredded cassava stem and vermiculite. Costa et al. (2012) obtained stem diameter ranging from 0.97 to $1.05 \mathrm{~mm} ; 1.14$ to $1.39 \mathrm{~mm}$ and 1.65 to $1.87 \mathrm{~mm}$ in eggplant seedlings grown in coconut fiber + organic compost; soil + organic compost and Plantmax + organic compost, respectively, at 40 DAS. Ferreira et al. (2014) obtained at 25 DAS values between 1.381 and $1.654 \mathrm{~mm}$ of SD in eggplant seedlings grown in substrates with bovine manure and small ruminants manure in different proportions.

It is believed that the lowest $\mathrm{SD}$ values obtained in this study in relation to those mentioned above may be associated with the phosphorus deficiency in the residues, as it can be observed in Table 1. In fully developed seedlings, the lack of this nutrient causes a smaller stem diameter. Zonta et al. (2010), evaluating simple superphosphate doses in the production of 'Ciça' eggplant in Cassilândia, concluded that the stem diameter presents an increasing response with increasing doses of simple superphosphate, so that the maximum dose used (3.0 t/ha) promoted an estimated value of $25.73 \mathrm{~mm}$. This result corroborates with Filgueira (2008), who affirms that there is an increase in the stem diameter, the leaf area, the size of the plant, among other characteristics, with application of $P$.
According to Figure $1 \mathrm{E}$, the estimated value of $12.76 \%$ of moinha in the substrate provided higher amount of FSB (265.182 mg), followed by $20 \%$ (257.942 $\mathrm{mg}$ ). The lowest value $(162.782 \mathrm{mg})$ was obtained in the substrate containing $40 \%$ of moinha.

For the FRB variable (Figure 1F), the estimated value of $20.98 \%$ of moinha provided the highest value ( $348.37 \mathrm{mg}$ ), followed by the proportion of 30 and $10 \%$, reaching values of 329.421 and $306.801 \mathrm{mg}$, respectively. The lowest value was obtained in the substrate containing 40\% (223.66 mg). These results were superior to those obtained by Costa et al. (2012) whose FRB values did not exceed $215 \mathrm{mg}$ in eggplants at 40 DAS in substrates with $86 \%$ of Plantmax $+14 \%$ of organic compound.

According to Figure $1 \mathrm{G}$, the estimated value of $18.59 \%$ of moinha provided higher TFB $(606.607 \mathrm{mg})$, among the treatments applied. The lowest value, $(384.918 \mathrm{mg})$ was obtained in the substrate containing $40 \%$ of moinha (Figure 1G). With results superior to those obtained in this study, Ferreira et al. (2014) found values of $1010 \mathrm{mg}$ of TFB in eggplant seedlings produced with vermicompost.

The shoot dry biomass is related to the quality and quantity of leaves (Moreira et al., 2010). This characteristic is important because the leaves are one of the main sources of photoassimilates and nutrients for seedlings adaptation. Thus, we found that the estimated value of $6.15 \%$ of moinha provided the highest value of SDB $(144.15 \mathrm{mg})$, while the lowest value $(57.94 \mathrm{mg}$ ) was obtained in the substrate containing $40 \%$ of moinha (Figure $1 \mathrm{H}$ ). Costa et al. (2011), studying the formation of eggplant seedlings in substrates with different percentages of shredded cassava stem and vermiculite, did not find values higher than $47 \mathrm{mg}$ for SDB, a result inferior to what was obtained in this study.

The residues used in the substrate composition should maintain an interaction with the plant and, the roots are responsible for this interaction. According to Costa et al. (2013), roots with adequate development are 
better able to withstand environmental changes, because the plant root system allows a greater area contact with the soil, due to the greater root dry biomass (RDB). Filgueira (2008) affirms that a good root growth and restarting the plant development due to plant stress after being replanted, are favored by tissues rich in dry biomass. According to Figure 1I, we verified that an estimated percentage of only $1.9 \%$ of moinha provided the highest value of RDB (132.02 mg), among the applied treatments. The lowest value $(49.26 \mathrm{mg})$ was obtained in the substrate containing $40 \%$ of moinha. Costa et al. (2011) studied the formation of eggplant seedlings in substrates with different percentages of shredded cassava stem and vermiculite, and did not find values higher than $18 \mathrm{mg}$ for RDB. Similarly, Costa et al. (2012) also did not find values higher than $38 \mathrm{mg}$ of RDB, at 40 DAS, in eggplant seedlings produced in substrate with $86 \%$ of Plantmax $+14 \%$ of organic compound. These results are well below the lowest value obtained among the evaluated doses of moinha.

The estimated value of $4.3 \%$ of moinh a provided the highest content of TDB (275.59 mg) (Figure 1J). On the other hand, the lowest value (107.64 mg) was obtained in the substrate containing $40 \%$ of moinha. Even so, the lowest value of TDB obtained in the higher dose of moinha was superior to the results found by Ferreira et al. (2014), who did not obtain values higher than $101 \mathrm{mg}$ of TDB in eggplant seedlings produced with vermicompost substrate.

Except for the variables SDB, RDB and TDB, in general the highest values obtained in the analyzed variables were 10 to $20 \%$ of moinha used in the substrates composition. With this increase, all variables presented decreasing values. It is believed that this fact could be associated to the higher salinity in the substrate, due to the greater electrical conductivity with the increase of the moinha in the substrate (Figure 1A). This may have contributed to the decrease of the osmotic potential in the substrate, negatively affecting the growth variables as a whole. Between 10 and $20 \%$ of the substrate, the effect of salinity did not predominate the beneficial effect of nutrients, especially in nitrogen, which is present in the moinha (Table 1). Nitrogen is one of the nutrients that most limits the biomass development and productivity of most crops (Maçãs, 2008), besides being considered one of the most relevant factors for increasing production, by influencing the emergence rate and leaf area expansion (Taiz \& Zeiger, 2009).

Satisfactory results obtained in these residues can lead to a lower production cost of eggplant seedlings, in addition to providing a noble and adequate destination of these residues in the environment.

From the obtained results, it is possible to conclude that increasing percentages of moinha provide an electrical conductivity increase in the substrate. The treatment groups containing increasing proportions of moinha in the substrate composition present the highest values of growth variables in relation to the commercial substrate. With the exception of the shoot dry biomass, root and whole plant, the substrate containing between 10 and $20 \%$ of moinha have the highest values of analyzed variables in eggplant seedlings.

\section{REFERENCES}

ANEFALOS, LC; MOREIRA,SR; VIEIRA, KM; CIPOLLI, AB; TURCO, PH; TAVARES, PER. 2008. Sazonalidade da oferta de produtos hortícolas: o mercado de berinjela. Campinas: ITAL. $17 \mathrm{p}$.

ARAMÉNDIZ-TATIS, H; CARDONA-AYALA, C; CORREA-ALVAREZ, E. 2013. Efecto de diferentes sustratos em localidad de plántulas de berenjena (Solanum melongena L.). Revista Colombiana Ciencias Hortícolas 7: 55-61.

ARAÚJO NETO, SE; AZEVEDO, JMA; GALVÃO, RO; OLIVEIRA, EBL; FERREIRA, RLF. 2009. Produção de muda orgânica de pimentão com diferentes substratos. Ciência Rural 39: 1408-1413.

CAMPANHARO, M; RODRIGUES, JJV; JUNIOR, MAL; ESPINDULA, MC; COSTA, JVT. 2006. Características físicas de diferentes substratos para produção de mudas de tomateiro. Caatinga 19: 140-145.

CARRIJO, OA; LIZ, RS.; MAKISHIMA, N. 2002. Fibra da casca do coco verde como substrato agrícola. Horticultura Brasileira 20: $533-535$.
CASTOLDI, R; GOMES, RF; CHARLO, HCO; MELO, DM; BRAZ, LT. 2014. Performance of cucumber hybrids cultivated in coconut fiber and soil. Horticultura Brasileira 32: 86-90.

COSTA, LAM; COSTA, MSSM; PEREIRA, DC; BERNARDI, FH; MACCARI, S. 2013. Avaliação de substratos para a produção de mudas de tomate e pepino. Revista Ceres 60: 675-682.

COSTA, E; DURANTE, LGY; NAGEL, PL; FERREIRA, CR; SANTOS, A. 2011. Qualidade de mudas de berinjela submetida a diferentes métodos de produção. Revista Ciência Agronômica 42: 1017-1025.

COSTA, E; PEGORARE, AB; LEAL, PAM; ESPÍNDOLA, JS; SALAMENE, LCP. 2012. Formação de mudas e produção de frutos de berinjela. Cientifica 40: 12-20.

FAVARIN, JL; DOURADO NETO, D; GARCÍA, AG; VILLA NOVA, NA; FAVARIN, MGGV. 2002. Equações para a estimativa do índice de área foliar do cafeeiro. Pesquisa Agropecuária Brasileira 37: 769-773.

FERREIRA, LL; ALMEIDA, AES; COSTA, LR; BEZERRA, FMS; LIMA, LA; PORTO, VCN. 2014. Vermicompostos como substrato na produção de mudas de berinjela (Solanum melongena) e pimentão (Capsicum annuum). Holos 30: 269-277.

FILGUEIRA, FAR. 2008. Novo manual de olericultura: agrotecnologia moderna na produção e comercialização de hortaliças. Viçosa: UFV. 421p.

HARTER, LSH; HARTER, FS; DEUNER, D; MENEGHELLO, GE; VILLELA, FA. 2014. Salinidade e desempenho fisiológico de sementes e plântulas de morango. Horticultura Brasileira 32: 80-85.

MAÇÃS, JES. 2008. Nitrogênio nitrico e amoniacal no desenvolvimento da parte aérea de milho cultivado em argissolo. Porto Alegre: UFRGS. 72p. (Dissertação mestrado).

MATOS, AT. 2015. Manual de análise de resíduos sólidos e águas residuárias. Viçosa: Editora UFV, $1^{\text {a }}$ ed. $149 \mathrm{p}$.

MENEGHELLI, CM; MONACO, PAV; HADDADE, IR; MENEGHELLI, LAM; KRAUSE, MR 2016. Resíduo da secagem dos grãos de café como substrato alternativo em mudas de café Conilon. Coffee Science 11: 329-334.

MOREIRA, MA; DANTAS, FM; BIANCHINI, FG; VIÉGAS, PRA. 2010. Produção de mudas de berinjela com uso de pó de coco. Revista Brasileira de Produtos Agroindustriais 12: 163-170.

NATALE, W; PRADO, RM; ALMEIDA, EV; BARBOSA, JC. 2008. Adubação nitrogenada e potássica no estado nutricional de mudas de maracujazeiro-amarelo. Acta Scientiarum 28: 187-192.

NAVES, MMV; PRADO, CMM; FERNANDES, DC; SERAFIN, IAB. 2007. Avaliação microbiológica do pó da casca de ovo e otimização da técnica de elaboração do produto. Pesquisa Agropecuária Tropical 37: 113-118.

PAIXÃO, MVS; SCHMILDT, ER; MATTIELLO, 
HN; FERREGUETTI, GA; ALEXANDRE, RB. 2012. Frações orgânicas e mineral na produção de mudas de mamoeiro. Revista Brasileira de Fruticultura 34: 1105-1112.

SANTOS, MR; SEDIYAMA, MAN; SALGADO, LT; VIDIGAL, SM; REIGADO, FR. 2010. Produção de mudas de pimentão em substratos à base de vermicomposto. Bioscience Journal 26: $572-578$

SILVA JÚNIOR, JAS; GHEYI, HR; DIAS, NS;
ARAÚJO, DA; GUEDES FILHO, DH. 2014. Substratos e diferentes concentrações da solução nutritiva preparada em água residuária no crescimento do girassol. Revista Ciência Agronômica 45: 696-707.

STEFFEN, GPK; ANTONIOLLI, ZI; STEFFEN, RB; MACHADO, RG. 2010. Casca de arroz e esterco bovino como substratos para a multiplicação de minhocas e produção de mudas de tomate e alface. Acta Zoológica
Mexicana 26: 333-34.

TAIZ, L; ZEIGER, E. 2009. Fisiologia vegetal. Porto Alegre: Artmed, 4.ed. 848p.

ZONTA, TT; BISCARO, GAB; TOSTA, MS; MEDEIROS, LF; SORATTO, RP; TOSTA, PAF. 2010. Doses de superfosfato simples na produção da berinjela 'Ciça' em Cassilândia (MS) Brasil. Agropecuária Científica no SemiÁrido 06: 07-13. 